\title{
Cognitive Aspect of Intercultural Communication
}

\author{
Svetlana Kurbakova \\ Military University
}

\begin{abstract}
Correspondence concerning this article should be addressed to Svetlana Kurbakova, Military University, 14
Bolshaya Sadovaya Street, Moscow, Russian Federation, 123001.E-mail: svetlanakurbakova@yandex.ru
\end{abstract}

\begin{abstract}
The research of cognitive aspects of intercultural communication is aimed to explore national linguistic consciousness, its peculiarities in order to determine the universal basics which make the intercultural communication possible while preserving national cultural identity and language diversity. This scientific analysis can become a background for developing skills of comprehending foreign speech and providing learning and teaching paths towards communication competence in accordance with Common European Framework of References for Languages. The analysis of texts has shown a fast-growing process of penetration of anglicisms into national languages which leads to obvious structural changes in the national languages. The effects of this interference on cognitive process should be studied and discussed as there is a strong awareness that substituting foreign verbal means for the native ones leads to weakening the immunity of the national language consciousness in general and undermines the national traditions of verbal communication approved and used by a national community. The linguistic analysis of professional activities of interpreters in the process of consecutive translation, students' experimental with work with texts and material for comprehension and translation in class, survey of psychological tests on perception mechanism made it possible to describe a cognitive scheme of human reflection and interpretation of the real world and its developments which make up the contents of perceived texts during listening and reading. The concept of a subject whose activities are performed at a certain place at a certain time can be given the status of a three-coordinate (subject, place, time) cognitive scheme. The didactic exploitation of this cognitive scheme is seen in teaching students to identify these coordinates in the process of comprehending speech or text and thus to perceive its message by structuring and organizing the information. It is thought to be an effective method of developing productive communication skills as well as to be a reliable scientific basis to create and exploit learning and teaching techniques of handling and integrating information, including that of taking notes and organizing received facts in the process of consecutive translation.
\end{abstract}

Keywords: cognition, cognitive scheme, translation, communication

The research of a cognitive scheme to develop receptive skills of listening and reading of foreign speech is aimed at constructing learning and teaching paths towards communication competence in accordance with Common European Framework of References for Languages.

Contemporary studies in linguistics and psychology have proved that verbal communication should be considered an interaction of people who are determined to cooperate. Life in society makes a person use words (of a native or foreign language) to communicate with other people in order to achieve his /her aims and satisfy his/ her needs. In short, a person handles his/her interlocutors, affecting their behavior, way of thinking, activity. On the other hand, social interaction obliges a person to correlate his/her speech with communicative situation which is characterized primarily by such parameters as agent(s), space and time. We call these parameters deictic coordinates. They form a framework of a verbal communication by correlating speech with relevant agents, space and time.

Our comparative analysis of grammar of different languages has discovered that this organization of verbal interaction has a universal nature, but engages specific means in different languages (Kurbakova, 
2014, pp. 131-139). It enables to enrich the traditional usage of the term of deixis in the theory of indication with explanation of its motives and functions in verbal communication. We suggest deixis should be interpreted as a linguistic mechanism of correlation between speech, subjective motivation and objective situation where and when agents act or plan their actions. Thus who, where and when shall constitute a backbone of discourse.

By implementing this mechanism in speech a person reflects the objective system of interaction but subjectively, in accordance with his/ her personal concepts of agent(s) (his/ her character, motivation, activity and proposed reaction to discourse). Moreover, the research has demonstrated national peculiarities of deictic words. In different languages we can observe different means of indication of agent(s), place and time of verbal communication. Most languages have special classes of deictic words (i.e. nouns and pronouns indicate agent(s), grammatical forms of verbs and corresponding adverbs indicate time, nouns with propositions and corresponding adverbs indicate space. Evidently, it is reasonable enough to determine the deictic potential and deictic scale of words in every language.

We suppose that this mechanism of coordinating verbal communication with the help of deictic markers of agent, space and time plays a basic role in speech interaction due to the following reasons. Firstly, it provides speech with structure an order thus enabling us to escape chaos in communication. Secondly, these deictic markers assist a person in comprehension and cognition of the world. Thirdly, we should state the dual character of these deictic markers: they indicate agent(s), space and time (which have objective nature) as a result of a person's mental activity thus integrating objective and subjective factors.

The concept of a subject whose activities are performed at a certain place at a certain time can be given the status of a three-coordinate (subject, place, time) cognitive scheme.

\section{Materials and Methods}

\section{Psychology of Speech. Text Organization}

Any text as a result of speech activities may be considered as a system integrating mutually dependent elements. A word can be characterized as a basic verbal element of a text. Verbal elements - signs - belong to the material world, but they implement the ideal world of human perception, conception and intention.

From the philosophical point of view the organization of a text as a verbal system is defined as its structure which supposes integration of verbal elements, their interrelationship. Thus a text can be considered as a system whose elements make up a whole product of both material and idealistic nature. Its contents should be interpreted as a combination of meanings of its verbal elements and correlations between them.

The research of speech communication as a system started more than five decades ago. It was Roman Yakobson who suggested that linguistics should analyse speech with consideration of all factors relating to it such as "inherent characteristics of verbal utterance itself, its addressant and addressee who is either actual or supposed by the addressant to be a recipient" (Yakobson, 1985, p. 319).

\section{Communicative Intention}

Text informativity is formed by information of its verbal elements and correlations between them. In its turn, when we consider the text structure and information it bears, we have to consider extra linguistic factors characterizing the communication situation and, first of all, the deictic triad - who, when and where performs some activities to fulfil one's intentions. We have already analysed the reason of usage of verbal means in speech in our previous works on deixis (Kurbakova, 2014, pp. 131-139). In our research we referred to the results of the Moscow school of psycholinguistics in exploring speech communication (Tarasov, 2005).

The correlation with extra linguistic factors of the text is reasonable enough as it is included in human activities in a situation when and where it is necessary to use speech with its verbal means to organize communication. The described deictic organization of a text is thought to be relevant to relations between subjects performing some activities in space and time. These relations are perceived by communication agents and implemented by them with the help of verbal (linguistic) signs in a text. It is obvious enough that the text should be described as a result of speech activities intended to produce some effect on a recipient. We believe it should be defined as the general intention of speech.

The above mentioned researches have proved that correlation between meanings of verbal (linguistic) signs in a text and situational factors. Before articulating an utterance an addressant shall perceive, analyse and reflect the real life situation where communication is held, accumulate information, firstly, about basic coordinates of agent, space and time, and store the perceptions as gained intellectual experience. For instance, on hearing an utterance ' $A n$ aircraft is flying high in the sky' a grown -up shall use his/ her experience which is stored in the form of concepts. His/her consciousness shall produce a picture of this 
activities on the basis of the cognitive scheme: who/ what performs these activities where and when. If it is necessary and, of course, possible, the addressee (recipient) shall specify what it is not clear to him/her and has to be defined more accurately.

In this context it is worth mentioning that our speech and consciousness don't coincide largely, in other words, what we say doesn't necessarily coincide with what we think about something. And moreover, we do it purposely: we don't pronounce all we keep in mind due to objective reasons and subjective motives. We won't dwell on this very interesting scientific problem of human psychology, speech communication, ethics and ethnics in this paper: it is planned to be the subject of our next report. But now we have to state that our speech is affected by numerous factors of intellectual, moral, physical, psychic, mental, ethical nature.

L. Vygotskey, a prominent Russian scholar, who achieved great results in the studies of psychology and linguistics, noted that perception is characterized by simultaneous developments in human consciousness, whereas speech is successive (Vygotskey, 1999, p. 318): "Verbal communication resembles a stream which combines various means of linguistic and nonlinguistic origin, speech elements are used purposely and intended to exert some impact on recipients, to manipulate addressees" (Vygotsky, 1999, p. 318).

\section{Results and Discussion}

\section{Cognitive Scheme. Deictic Triad}

Recent researches have proved that elements of the text are not equal as far as the amount and value of the information and impact they possess. It means that human perception and reflection of the outer world is carried out by highlighting the most important information.

The concept of a subject whose activities are performed at a certain place at a certain time can be defined a cognitive triad (subject, space, time). Obviously we can give this triad a status of basic cognitive scheme which enables us to understand the meaning of a text as a whole. On the other hand, basing on these coordinates - who, where and when communicating agents may describe the situation relevantly. Firstly, the deictic scheme provides speech with structure and order thus enabling us to escape chaos in communication. Secondly, these deictic markers assist a person in comprehension and cognition of the world. Thirdly, we should state the dual character of these deictic markers: they indicate agent(s), space and time (which have objective nature) as a result of a person's mental activity thus integrating objective and subjective factors in communication.

It is worth mentioning that this scheme helps transform mental elements into speech elements. This transformation is believed to be very complex and evasive to apprehend and describe.

\section{Quantum Structure}

We suppose that a text has a quantum structure. We consider that deictic words imply the most important information about the communicative situation. In this context we should dwell on such a phenomenon as lingual redundancy which was first defined in the works of R. Minyar-Beloruchev (MinyarBeloruchev, 1996). To illustrate this phenomenon we can analyze any SMS message. In order to minimize a text to print only important (communicatively reasonable) information is given in such texts: i.e. request-message "Where are you?" - answer-message "At home", "Who is in charge?" - "Me", "When will you come?" - "Tomorrow". We often use O.K. to agree to something. All forms of military commands and salutes are believed to be reasonable illustrations of the attempt to avoid redundancy in speech.

\section{Verbal Redundancy}

The reason for the phenomenon of verbal redundancy in speech can be found in human mental mechanisms of processing the received information from the outer world: information is accumulated unevenly by various elements of an utterance, with deictic words bearing the biggest amount of information about who, where and when perform some activities.

We think it is reasonable enough to compare an utterance in speech with wave process: in order to draw the partner's attention to some component of the communicative situation the corresponding element is verbalized explicitly while the rest components are perceived from presuppositions. In outer speech only one deictic parameter may be indicated while the rest - clear from the previous utterances - are not verbalized.

Hence, students should be trained to process the information they perceive, to single out the informative peaks - deictic parameters we have described earlier, to reproduce this information in translation relevantly. This skill is of vital importance not only for interpreters but also for pilots and servicemen. The researches have shown that verbal redundancy in radio traffic communication is estimated at the level of $96 \%$.

\section{Consecutive Translation. Precision Information}


The analysis of verbal redundancy in a text has proved the necessity of the deictic cognitive scheme which helped to formulate a theoretical platform for practical skills of comprehending and reproducing texts both in native and foreign languages. This practice is of invaluable assistance in consecutive translation.

Consecutive translation is characterized by fast switch from one language to the other in the process of interpreting of the original text. The interpreter does his/her best to catch the most important information in the text by memorizing, first of all, who, where and when performs the activities described in the text. To memorize these facts which are called precision information, because they must be translated absolutely precisely, an interpreter concentrates his attention and tries to take notes of these coordinates. Then he/she shall make use of these notes to translate accurately.

The deictic cognitive scheme proves to be grounds for methods and principles of concise recording of information in the process of consecutive translation. Admitting the fact of verbal redundancy in an utterance we suppose that an interpreter should focus on the most informative elements of the speech, predominantly the deictic parameters.

\section{Prognostication}

When students are taught to apprehend a text on the basis of the deictic cognitive scheme it enables them to process information relevantly and effectively, and even to assess and prognosticate the results of communication.

The studies of psychological mechanisms of speech and translation we have referred to above, demonstrated that prognostication is quite possible because speech consists of interrelated elements. From the informative point of view elements of the utterance may have different information potential: there are some elements referring to the situation which has already been described and perceived by communicating partners. Those elements which bear no new information can be called as redundant as they comment or explain what has already been mentioned. Such elements are defined as commentary to the topic which implies new, most important information about the situation.

Thus we may conclude that elements of the utterance bear different information value: some are redundant and may be omitted, and some imply the intention of the communication. There is a very important point: information in a text is concentrated on deictic peaks composing the cognitive scheme, the focus of the communicative act.

\section{Informative Value of Speech Elements}

Due to different informative value of elements an utterance may be divided into segments possessing different information potential. The deictic triad may be considered a basis to perceive, evaluate, reproduce, assess information. As we have noted verbal means are characterized by different potential of indicating deictic parameters of the situation. Moreover the use of deictic linguistic signs is determined by subjective characteristics of the agent depending on his/her communicative intentions.

We believe that the deictic triad plays the role of objective framework of an utterance in speech, but this coordinates are implemented in speech due to subjective reasons and intentions, general purpose of communication. On the other hand, we can assess the motives of a speaker judging from verbal means used in his/her speech to name subject, place and time. Let's appreciate the efforts a translator / interpreter does to translate adequately. The following example shows how important is the information included in indication of subjects, and how different are verbal means used in different communication surroundings. This advice is given by Lynn Visson: "Since today's world newspapers, radio and television programs around the globe are all too often filled with accounts of terrorist attacks, suicide bombings and other such horrific acts, the Russian-English/ English Russian translator or interpreter is well advised to have a variety of synonyms in his active linguistic baggage... The individual who carries out such acts is the 'perpetrator', and he 'commits', 'carries out' or 'perpetrates' his evil deeds. The individuals who order him to do so 'заказчики' or 'зачинщики' are the 'masterminds', 'ringleaders' or 'instigators' of violence. While the word 'бандиты' often comes up in reference to terrorists, the English word 'bandits' should be avoided. A far better translation is 'thug', 'пособники' or 'приспешники' of terrorists are their 'henchmen', 'accomplices', or those who aid and abet terrorists'" (Visson, 2002, p. 48).

The deictic cognitive scheme is regarded as a theoretical basis for analysis of verbal communication in modern society both at national and global levels: the associative responses to stimulus words denoting agents in some communicative situation may be considered from the scientific point of view as demonstration of social climate including relations between ethnic and religious communities. Contemporary studies in psycholinguistics are developing methods of assessment of moral climate in modern societies, i.e. degrees of aggressiveness between ethnic groups and confessions (Tikhonova, 2014), and the deictic cognitive scheme may be attached to effective tools for linguistic diagnosing. 


\section{Grammatical Aspects}

From the grammatical point of view the utterance usually corresponds to a sentence with its grammatical structure: in most languages we try to analyze subject and predicate, as they imply the most valuable information about the situation and activities, and adverbial modifiers of time and place which specify the information given by subject and predicate. Thus we may define the deictic triad - who, where, when (WWW) - as the cognitive scheme to organize information in speech.

The application of the WWW in comprehension enables us to define the so-called information bits: i.e. the analysis of the following sentence 'Yesterday the French President arrived in Brussels on a two-day visit' on the basis of the deictic triad may provide such information bits as who - French President, where Brussels, when - yesterday. The verb in its grammatical form predominantly provides information on activities, and this basic information is completed by other modifiers.

\section{Lexical Aspects}

In this paper we'd like to dwell shortly on a very interesting problem of intercultural communication which is closely connected with implementation of the discussed cognitive scheme, namely the personal coordinate (subject/who) in written texts.

Personal (proper) names of characters in literature are very difficult phenomenon for perception and translation because they imply a great deal of cultural information referring to national traditions and way of life. We shall give one example: V. Garshin, a Russian writer (XIX century), wrote a story titled "Signal" (Garshin, 1981) where he describes the character of Semen and his wife and how they sought their luck by moving from one place to another: 'Пришлось им в своей деревне невтерпеж; пошли на новые места счастья искать. Побывал Семен с женой и на Линии, и в Херсоне, и в Донщине, нигде счастья не достали'. As this story was written in late 1880s it is necessary to explain that Semen is travelling about kasak lands along the Don river, Liniya is a chain of fortifications on southern borders of the Russian state, close to ancient Kherson in the south of Russia. We have analyzed the translation of the story given by Lizzie B. Gorin in 1907. We have concluded that the translator found an adequate method of interpreting the geographical names of Donshina and Kherson which bear very important historical information in the text: she adds government to the proper name to explain the status of the territory, but obviously she failed to find similar explanation of Liniya and made a decision to omit this information, but most texts don't bear such loose approach to interpretation. This is the translation by L. Gorin of this paragragh: 'They could no longer stay in their native village, and decided to go into new places in search of better luck. Semen lived with his wife on the Don for some time, and in the Government of Kherson, but they somehow couldn't get along very well anywhere'.

Another example from modern literature underscores the point regarding translating cultural content. In the novel The Edge of Reason (Filding, 2001) H. Filding uses two geographical names Pompeii and Slough as characteristics of way of life (not only to mark the place). It is common knowledge that Pompeii perished due to disastrous volcano eruption which nobody could predict. But the name of Slough, a calm outskirts of the big city, is clear to the those who live in London. That is why a translator should provide explanation to create an adequate picture of the described situation: 'Just imagine if Pompeiistyle volcano erupted south of Slough, and everyone was preserved in stone on bicycles wearing puppies, eiderdowns and daughters, future generations would come and laugh at spiritual emptiness of it'.

Modern literature provides numerous examples of usage proper names of personalities or celebrities which are known only in the national culture of the original language, and a translator has to provide this exta linguistic information in comments, because these names are important to describe the character. The following examples are taken from the mentioned above book by H. Filding: 'I' $m$ thinking bunny girl, I'm thinking Gladiator, I'm thinking canvassing MP. I'm thinking Chris Serle meets Jerry Springer meets Anneka Rice meets Zoe Ball meets Mike Smith of the Late, Late Breakfast Show' (Filding, 2001, p. 11), 'Everyone knows that Anjelica Huston never, ever rang Jack Nicholson, and that men cannot bear not to be the pursuer' (Filding, 2001, p. 17), 'I'm sportswoman in mannerof Princess Anne!' (Filding, 2001, p. 37), 'A rather more attractive version of George Clooney" (Filding, 2001, p. 102). All these names seem unfamiliar to readers who are not part of the English language culture, but they are used by the writher purposely, and they bear information about the communicative situation described in the book, and if this book is translated, the translator should do his/her best to provide adequate extra linguistic information. And then it is up to a reader to like this literature or not, to accept such cultural values or not. In this context, we have to recognize that translated literature can be used as a tool of promoting foreign cultural values and traditions

\section{English Loanwords in National Languages}

In the modern globalizing world the problem of saving individual characters of national languages 
is extremely acute. As a result of expansion of the English language which claims to be lingua franca, many European and Slavic languages see the formation of a pseudo-English language which is not only used in intercultural communication, but in the communication between members of one non-English language community. English borrowings in many languages are treated as native words. They cram mass media from advertising to television, radio and press, we can see them on signboards in the streets. Thus, the penetration of anglicisms into other languages affects the formation of the linguistic consciousness of the younger generation and results in the socalled conglomerate phenomenon, that is mixing of national languages with the English language. This phenomenon can not be called borrowing because it does not interact with the language system of any national language but destroys it and causes largescale structural changes. English loanwords that enter national languages often clutter up them.

For example, in the German language there is a phrase Zukunft-Energieren: jetzt active gemanagt (gemanagt instead of geregelt). In the example above the English verb to manage has preserved the phonetic form of the English root but in order to form the past tense it has been changed in accordance with the rule of forming the past participle in the German language. Besides, such lexical units as Bühnenshow, Flugticket, Pattencover, Erfolgsstory, Iobeinsteig, Business-toConsumer-Geschäft, Partnerlook etc. are widely used.

In the French language there are such expressions as le goût du relooking, la Star, job principal - foreground job, il a un bon job - he has a good job; faire shopping, faire jogging [dzogin], il y a du love dans l'air; C'est vraiment une success story and others.

While the English language penetrates the German and French languages more or less smoothly due to their common origin, the process of incorporation of anglicisms into the Russian language, that does not have "blood kinship" with English has a negative effect on the language structure integrity of the Russian language and contributes to the loss of its expressiveness. Thus, such phrases as прекрасный лук [luk] from the English look (instead of стиль или внешний вид in the Russian language), опенинг [əpənıf] from the English opening or эндинг [əndıf] фильма from English ending of a film (instead of «начало или конеи фильма» in the Russian language), to say nothing of the expression «делать шопинг" (instead of «делать покупки») are used quite often, especially by young people.

The preliminary results of recent research into structural changes in the Russian, French and German languages have demonstrated the expansion of anglicisms in the system of each language under consideration in all spheres of speech activity of national communities.

The linguistic phenomenon of borrowing new words has proved to be quite reasonable due to progress in technological and scientific spheres as well as in social communication, especially intercultural. Being a dynamic open system of verbal signs, a language carries out its task of a means of verbal communication both at a national and international, strictly speaking intercultural, levels by developing its own linguistic resources. This development includes a step-by-step process of borrowing new words, mainly scientific and technical terms. The fast developing information technologies provide an enormous corps of such terms: these English loanwords are widely used in professional IT communities and by nonprofessionals who use various electronic devices, gadgets, PCs, etc. For instance, we have witnessed the use of the term multiplex with the meaning of a set of TV and radio broadcasting channels employing the same digital channel, in French, German and Russian: French - Multiplex, German - Multiplex, Russian мультиплекс; the same goes to the English monitor: монитор [monit'or] in Russian, moniteur in French, der Monitor in German. The English media is used in German die Medien, in French les médias, in Russian медиа [media].

The French language has assimilated the English blog without any changes: le blog [blog] ; blogue (meaning Web-site), the same goes to the Russian блог [blog]. But the German has preferred das Webseit (Webseit which is a synonym of blog).

The English word interview has penetrated into the French language with slight phonetic changes une interview [c̃tervju]: accorder interview à - to give smb an interview; into German and Russian without any changes: das Interview [-'vju:], интервью [interv'yu]. The same goes to the English Internet : das Internet in German, Internet, réseau Internet in French; интернет in Russian.

The English hacker has been transliterated by Russian into хакер ['haker] (naming a person violating computer network), by German into der Hacker ['hekər]. But the French language has preserved its national word combination le pirate informatique which functions simultaneously with the English loanword le hacker ['aker]. But the English gadget and device have anchored only in the Russian as transcription гаджет and its synonym девайс without any changes in their meaning. It is necessary to point out that in the Russian language there are its own verbal means to determine those things "техническое устройство, приспособление, техника". And the English networking has anchored only in the French vocabulary: le networking (le réseautage). 
We consider that this process of borrowing technical terms to name innovations in the spheres of science and technology can be justified by natural reasons: a product invented or created is named by its inventor or creator in his/her native language or mainly according to the language spoken in the professional community, i.e. English in the sphere of information technologies.

Simultaneously, we harbor great concern with the other trend in using loan words: substituting foreign verbal means, including word and word combinations, grammar rules, word order, for the native ones. We believe that the language spoken by an ethnic community is the basis of its culture. The unreasonable expansion of Anglicisms can be considered as a threat to national cultural traditions since the substitution both of foreign (in our case) English vocabulary and grammar for national verbal structures, and of foreign ideas and values for national ones.

It has been proved that every word (text) should be assessed by its message to the recipient. Contemporary studies in linguistics and psychology have proved that verbal communication should be considered an interaction of people who are determined to cooperate. Life in society makes a person use words (of a native or foreign language) to communicate with other people in order to achieve his /her aims and satisfy his/ her needs. In short, a person handles his/her interlocutors, affecting their behavior, way of thinking, activity.

The process of acquisition of a national language is considered as a profound component of acquisition of national traditions, values, culture and finally, national identity. The language plays a basic role in forming a human personality by providing information about national perception of the world, mentality and ethics. The tradition of analyzing correlation between a national language and national character goes back to W. von Gumboldt (Gumboldt, 1984). J. L. Weisgerber (Weisgerber, 2004) wrote about a language as intermediary between a person and the outer world. The language is designated to implement intellectual, spiritual, cultural advance. The language possesses specific power to formulate personal perception of the world, and in this way it effects the national culture. Any national language may portrays cultural, including intellectual and moral, characteristics of both a person and nation he/she belongs to. Every national language is thought to be an instrument of verbal communication of the corresponding nation: it verbalizes the concepts formed by the nation. These peculiarities are determined by extra linguistic reasons, first of all, by national traditional spiritual values, activities and way of life (Kurbakova, Kurchenko, 2014).
In the sphere of culture, especially music and cinema, the usage of terms of the English origin to name new phenomena which are also mainly of the English origin, is quite natural and reasonable. For instance, the English rock functions in Russian like pok [rok], in French - le rock, in German - der Rock, as well as in their derivatives: rock and roll - рок-нролл in Russian, le rock (and roll) [rok(cnrol)] in French.

The languages under consideration borrowed jazz: джаз [dzæz] in Russian, der Jazz [dzæz] in German, le jazz [dza:az]) in French and its derivatives: джазбанд (бэнд) in Russian, die Jazzband ['dzæzbent] in German, le jazz-band [dzazbãd] in French after the English jazz band. We can also find the Russian джазмен (to name a member of a jazz-band), the French jazzman [dzazman] (jazzmen), the German der Jazzmusiker which derived from the English jazzman. It is worth mentioning that the German language tried to adapt the word to its grammar rules. The English music term soul (a genre of Afro-American music) is used by musicians in Russian like a transcription -соул, in German like a transliteration with slight phonetic changes Soul [so:l], in French - soul [sul]. The same goes to the following music terms: hit, singl, track, soundtrack, poster. The words were borrowed together with the cultural phenomena. Their origin is quite clear.

But what is the reason for substituting the English starfor common words in national languages? Nowadays we can read about star in the meaning of "celebrity" in German der Star [st-], in French le star [star]) in the same context. In the Russian language this word of the English origin is alien to the normal Russian tradition, it is widely imposed on the public by mass media and advertisements: Синема Стар [sinema star] (the name of a cinema), Cynepcmap [superstar] (the name of a film, "СуnерСтар" - Ты узнаешь её" (advertisment).

The three languages under consideration employ the English thriller: триллер ['trilər] in Russian, le thriller [srilœr, tri-] in French, der Thriller [' $\theta$ rilər]) in German; the English remake: римэйк [rI'me:k] in Russian, le remake [Rimek] in French, das Remake [rI'me:k]) in German; the English show: moy in Russian, le show in French, die Show [Jo:], die Schau in German.

It is very important to highlight the fact that the English loanwords can enrich their meaning by additional connotations on the basis of metaphor which is usually based on national cultural traditions of conceptualization (Ganyushina, 2014, pp. 3340). It proves the proposition that foreign concepts may penetrate and even distort national linguistic consciousness interfering with progress of a national language. For instance, the English word flash has lately enriched its meaning and nowadays it is used in the French with all its connotations: le flash "light, inspiration, memories", e.g. 1) Cest en mangeant 
un Mister Steer, à côté du cinéma Parisien, que jai eu mon FLASH: il y avait peut-être un moyen de rejoindre Mathieu, après tout, sans avoir à attendre l'ouverture de La Cachette (Tremblay, 1992, p. 50). The Russian language employs this anglicism флеш only in the meaning of "urgent short interview or report from a scene of action". The German language - der Flash in the meaning of short shot or a moment when a drug has the first effect. Meanwhile the French has borrowed the English scoop - un scoop (avoir la primeur, en exclusivité) to name the priority of publishing some urgent (fleshy) news. These linguistic facts may prove that an anglicism penetrating in various languages can accumulate different meanings which can't be considered as a valid basis for intercultural communication. In this context the role of the English language as lingua franca remains doubtful.

Moreover, the interference of anglicisms into national languages provide arguments to assume that their usage in speech is alien to native speakers as they often don't understand the meanings of new, 'trendy', foreign words which can provoke misunderstanding and commotion. Let's discuss some examples.

The English manager has interfered in the German vocabulary as der Manager (instead of the German term der Geschäftsführer), in the French - le manager (instead of the French words: le chef, le directeur, le gérant, le gestionnaire), in the Russian - менеджер or sometimes even манагер. Moreover, in Russian the manager is applied not only to some authoritative leader, but also to those who are involved in retail or wholesale: менеджеры по продажам, менеджеры по закупкам, etc.

The following illustrations may also testify to our proposition:

the English provider - German der Provider, Russian - провайдер, but in French we have failed to find this anglicism;

the English merchandising-Russian мерчендайзинг ['mœ:təondaezin], (this word sounds strange for the Russian phonetics), German das Merchandising ['mœ:tfəndaezin], French le merchandising [merfãdajzīj] (вместо le marchandisage ), but it is interesting to note that the English merchandiser has penetrated only the Russian vocabulary (fortunately not commonly used) мерчендайзер. The same refers to the English realtor - Russian риэлтор;

the English dealer has different meanings and connotations in French, German and Russian: der Dealer ['di:lər] - 1) a person involved in trade, 2) a person involved in drug traffic; le dealer - a person working on the exchange; in Russian дилер - a person involved in retail or wholesale trade, professional on the exchange. The English leader is widely used now in German - der Leader, in French - le leader [lidœe], as well as its derivative le leadership, in Russian лидер.
The analysis of every day speech of common people has shown that some anglicisms have become very trendy and popular among especially young people who are learning English at school or in colleges. This tendency should not be ignored: children and students, parents and teachers, scholars and writers all those who are involved in work with a national language, even teachers of foreign languages, should pay major attention to their national language and culture. Teachers of foreign languages are supposed to get students acquainted with linguistic diversity, other national languages and traditions teaching them to cherish and maintain their own language, national culture and values. Let's discuss some illustrations.

In the languages under consideration the English shopping is used instead of their national verbal means: in French le shopping, in German das Shopping

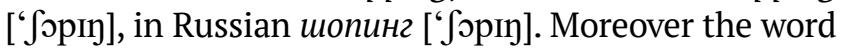
combination to do shopping was transliterated into Russian (делать шоппинг). Though the modern Russian language doesn't suffer from scarcity of verbal means to name this phenomenon: совершать покупки, бродить по городу с посещением магазинов. The same refers to:

the English business - le business in French, das Business in German, бизнес in Russian;

the English outsider - l'outsider in French; der Outsider in German (alongside with der Außenseiter), aymcaŭdep in Russian,

the English racket - das Racket ['rekət] in German, le racket [Raket] in French, рэкет in Russian;

the English freelancer - der Freelancer in German, фрилансер in Russian, but there is no such anglicism in French;

the English book can be found only in French: le book as a note-book, but its derivative overbooking is used in French press - l'overbooking (instead of la Surréservation). It is worth mentioning that this word has interfered in the Russian language - овербукинг: this phenomenon is being discussed in mass media, but is not described in any official document.

It is evident that mass media make a major "contribution" to this verbal substitution. For instance, the anglicism draft was used in Le Monde as 'a variant of a text': "Le Monde a réussi à se procurer le draft ("bouillon") de l'accord souhaité à Copenhague ...Un texte mis au point, en secret, par la Chine avec le Brésil, l'Inde, l'Afrique du Sud et le Soudan - en tant que président du G77, qui regroupe les pays en développement. Ce document confidentiel est leur réponse au texte..., ce document est intitulé "Copenhagen accord (draft) (Multiplication). In the Russian language anglocism дpaфm is used in business sphere alongside with the word проект. In German there is a term Draft-Modus with the meaning of 'special regime for printing'.

Recent researches of modern German have proved that official vocabulary coexists with commonly 
used anglicisms, e.g. the English team prevails over die Mannschaft not only in sport. Usually the process of borrowing is implicit: correspondents describing the US policy use the word Administration avoiding the national Regierung, interpreters practice DallasDeutsch in numerous films about the American way of life using alien word and word combinations like keine Idee instead of keine Ahnung; wir sehen uns später instead of bis dann; ihr Jungs instead of ihr.

The expansion of information technologies and Internet has caused appearance of such words in the Russian language as gadshety (from gadget), servery (from server), vebsayty and vebmastery (from website and webmaster), lep topy (from laptop), tehnicheskiye pisateli (from technical writers) instead of a Russian word combination "sostaviteli tehnichesloy dokumentazii", fleshky (short from flash drive), karty pamyati (from memory cards), draivery (from англ. drives), MP [эм пэ] pleyery (from MP player) and even verbs to indicate actions: laiknut' (from to like), chatit'sya (from to chat), zachekinit'sya (from to check in) instead of the commonly used Russian word "zaregistrirovat'sya", etc.

This tendency to substitute foreign - preferably, English - words for ones from national languages can be seen in speech of not only young users of Internet, but also teachers and professors: we have managed to collect about 40 anglicisms from a 40-minute report of a Russian speaking lecturer. It seemed that she was speaking the so called Russian English:

- "draft (from draft) programmy obycheniya" instead of "proekt",

- "investirovat' (from invest) vremya $v$ podgotovku studentov" instead of "tratit' vremya na podgotovku studentov",

- "topovaya pozitsiya (from top position)" instead of "vysokaya dolshnost",

- "trebovat' professional'noy expertizy “ (from professional expertise) instead of "professinal'nych navykov",

- "turnove (from turnover) personala" instead of «smena kadrovogo sostava";

- “эссессмент (from assessment) zentr" instead of "zent ozenki (professinal'nych kachestv personala";

- "simulyaziya (from simulation)" instead of "modelirovaniye situazii";

- "guru menedshment"(from guru and management) instead of "primer nastavnika";

- "biznes keisy" (from business case) instead of "sluchai iz praktiki"; "zapadniye keysy" instead of "sluchai iz proaktiki zapadnych kampaniy";

- "brending" (from branding) prepodavateley» instead of "poddershka prepodavateley na rynke truda";

- "znat' svoi biznes" (from business)» instead of "znat' svoy delo";

- "strategicheskiy [эйч ap] HR (from human resources)» instead of "strategiya razvitiya kadrov";
- "motivazionniy spiker" (from motivation and speaker)» instead of "agitator";

- "reyting" (from rating) instead of "ozenka".

The mentioned above facts show that the process of English interference in national languages is uneven. Further research is needed to analyze why some anglicisms easily penetrate the system of national languages, how national languages can resist this interference.

\section{Process of Consecutive Translation. Perception and Reflection}

The deictic scheme provides relevant comprehension of speech: every segment of speech may be defined as materialized and verbalized designation of subjective conceptions. There are moral, political, physical factors that influence the transformation of perceived and stored information about the outer world into material signs of language.

The process of consecutive translation has a complex nature and can be divided into three stages of processing information of the text which the interpreter receives: perception of the text in the original language, transformation of it into corresponding lingual system, reproduction of the interpreted text. Reflection is a simultaneous process going along with perception of linguistic signs in speech. That's why the skill to single out information peaks in speech is given so much attention. It is assumed as a very important component of translation competence: while in everyday communication a recipient highlights the deictic triad unconsciously, interpreters and translators are trained to do it purposely.

\section{Symbols to Record Rrecision Information}

The deictic scheme provides the theoretical foundation to develop skills of taking notes during consecutive translation: the WWW information is recorded with the help of special symbols. In early 1970s R. Myniar-Beloruchev, a prominent linguist and interpreter, suggested a system of special symbols substituting the most important segments of speech which mustn't be distorted or missed: i.e. $\square-a$ country; $\circ$ - negotiations; $\uparrow$ - movement forwards (progress, improvement, development, increase); $\downarrow$ - movement downwards (regress, decrease, degradation). It is worth mentioning that most symbols are to substitute concept, like progress, improvement. Most intention is paid to personal and geographical names, dates, time, characteristics of action. Such words as say, comment, point out, note, state, etc. introducing the direct speech are substituted by the : symbol.

Many symbols from the Myniar-Beloruchev system are not relevant any longer due to different reasons, 
but the methodology deserves refreshment and further development.

There is another important point: when taking the notes an interpreter should follow the so called principle of verticalism: information should be organized vertically on a sheet of paper to avoid misinterpretation. First comes subject (who performs some activities), down to the right - predicate characterizing the action and then down the page - modifiers of place and time.

\section{Experiment}

The hypothesis of the WWW cognitive scheme has been verified by the latest experiment with students of the faculty of foreign languages learning English to become interpreters. 42 participants were divided into two groups: the first group (20 students) consisted of undergraduates who were taught to use the system of symbols to take notes during the consecutive translation, and the second group (22 students) included the so called freshmen (first and second year students). They were asked to perform consecutive translation of the followings texts which were read once each:

Text 1: 'The Sochi 2014 Paralympic Winter Games will open on Friday (7 March), kicking off nine days of action which will see 547 athletes from 45 countries compete for 72 gold medals, with pictures beamed to a record 55 plus countries around the world' (BBC News, March 6, 2014).

Text 2. 'People in Scotland are voting on whether the country should stay in the UK or become an independent nation. Voters will answer "Yes" or "No" to the referendum question: "Should Scotland be an independent country?" With 4,285,323 people - 97\% of the electorate - registered to vote, it is expected to be the busiest day in Scottish electoral history. Votes will be cast at 5,579 polling stations until 22:00 on Thursday. The result is expected on Friday morning' (BBC News, September 18, 2014).

The first text comprises 43 words. 16 students (80\%) from the first group has accomplished the task without taking notes. They managed to memorize the precision information. 4 students (20\%) used symbols to grab the information about subject and time. The second group tried to use their own marks to put down the precision information: as they didn't train the systematic usage of symbols they had to create their own symbols to mark the WWW information.

The second text comprises 48 words. It contains much more precision information. 20 students (100\%) from the first group put down the WWW facts with the help of symbols. It is necessary to mention that symbols used by the students differed, they demonstrated each student's mental work of perception and conception. But all notes described the situation on the basis of the WWW triad. The second group demonstrated that students were not prepared enough to analyze the information and some (12 students) tried to write down the text like a dictation thus failing to catch the whole of the text. The rest (10 students) managed to take notes of the precision information of the WWW scheme but their symbols were not systematical: they need to be trained to use symbols according to the order which will optimize the process of translation.

\section{Didactic Exploitation}

We should make the future translator/ interpreter aware of the deictic scheme as it proves to be an effective tool of perception of information in speech communication.

Special exercises are being worked out to train the skill to single out the WWW information in a text to be translated/ interpreted: i.e. 'Take notes of historical dates, personal names, geographical names, time, etc. There are some very important didactic points.

First, students should be trained to catch subjects and their activities, then to enrich the report with data about characteristics of the action, including place and time.

Secondly, training process should be successive and intensify from easy things to more complicated data.

Thirdly, students may be free to create their own symbols to take notes of precision information but they should be organized into a system which can be reproduced.

\section{Conclusion}

The linguistic analysis of professional activities of interpreters in the process of consecutive translation, students' experimental with work with texts and material for comprehension and translation in class, survey of psychological tests on perception mechanism made it possible to describe a cognitive scheme of human reflection and interpretation of the real world and its developments which make up the contents of perceived texts during listening and reading.

The concept of a subject whose activities are performed at a certain place at a certain time can be given the status of a three-coordinate (subject/who, place/where, time/when) cognitive scheme (the WWW scheme).

The didactic exploitation of this cognitive scheme is seen in teaching students to identify these coordinates in the process of comprehending speech 
or text and thus to perceive its message by structuring organizing, assessing the information.

\section{References}

de Beaulieu, M. (2010). Multiplication des emprunts à l'anglais et accélération de l'évolution du français contempora. Retrieved from http://www.un.org/ fr/events/frenchlanguageday/pdf/anglicismes MdeBeaulieu.pdf

Fielding, H. (2001). Bridget Jones: The edge of reason. London, UK: Picador.

Ganyushina, M. A. (2014). Symbolic component of the concept blood in English and Russian language image of the world. In Mirovoye kulturnoyazykovoye i politicheskoye prostranstvo: Innovazii v kommynikazii. Moscow, Russia: TransArt.

Gumboldt, W. (1984). Izbrannye trudy po yazykoznaniyu [Selected works on linguistics]. Moscow, USSR: Progress.

Kurbakova, S. (2014). Basic mechanism of verbal interaction. In The International Multidisciplinary Scientific Conferences on Social Sciences and Arts (Vol. 1, pp. 131-139). Albena, Bulgaria: STEF 72. doi: 10.5593/sgemsocial2014/b13/S3.018

Kurbakova, S., \& Kurchenko, A. (2015). Paths to upgrade social and cultural competence of students learning foreign languages. In L. Gomez Chova, A. Lopez Martinez, \& L. Candel Torres (Eds.), 9th International Technology, Education and Development Conferenc (pp. 5317-5323). Madrid, Spain: IATED.
Minyar-Beloruchev, R. (1996). Teoriya i metody perevoda [Theory and methodology of translation]. Moscow, Russia: Moskovskiy litsey.

Tarasov, E. F. (2005). Proizvodstvo rechi: Bolshaya programma. In Yazik. Soznaniye. Kultura (pp. 3243). Moscow, Russia: Kaluga.

Tikhonova, E. (2014). Linguistic diagnosing of religious relationships through word association responses. In The International Multidisciplinary Scientific Conferences on Social Sciences and Arts (Vol. 1, pp. 505-516). Albena, Bulgaria: STEF 72. doi: 10.5593/ sgemsocial2014/b13/s3.068

Tremblay, M. (1992). Le coeur découvert [Open heart]. Montréal, Canada: Bibliothèque Quèbécoise.

Visson, L. (2002). Terms for describing terrorism. Retrieved from www.lingvoda.ru/transforum/ articles/L_Visson.asp

Vygotskey, L. (1999). Myshlenie i rech [Intellectual and speech activities]. Moscow, Russia: Labirint.

Weisgerber, J. L. (2004). Rodnoy yazyk i formirovaniye duha [The native language and morale evolution]. Moscow, Russia: Editorial URSS.

Yakobson, R. (1985). Yazyk $v$ otnoshenii $k$ grugim sistemam kommunikatzii [Language in relation to other communication systems]. Moscow, USSR: Progress.

Garshin, V. (1936). Signal [The signal]. Moscow, USSR: Izdatelstvo detskoy literatury of Komsomol Central Committee.

Garshin, V. (2011). Shto tak ne proizoshlo. Vstrecha. Signal. Chetyre dnya [What never happened. The meeting. The signal. Four days]. Moscow, Russia: Kniga po trebovaniyu. 